\title{
Enzymatic Synthesis of Polyphenol Glycosides by Amylosucrase
}

\author{
Hyunsu Park', Kyoung-Hwa Choi', Young Don Park', Cheon-Seok Park ${ }^{2}$ and Jaeho Cha ${ }^{1}$ * \\ ${ }^{1}$ Department of Microbiology, Pusan National University, Busan, 609-735, Korea \\ ${ }^{2}$ Gractuate School of Biotechnology and Institute of Life Science and Resources, Kyung Hee University, Yongin 449-701, Korea
}

Received October 31, 2011 /Revised November 18, 2011 /Accepted November 18, 2011

\begin{abstract}
The capability of synthesizing polyphenol glycosides was examined using recombinant amylosucrase from the hyperthermophilic bacterium Deinococcus geothermalis. Based on the action mode of amylosucrase, sucrose and twenty-one polyphenols were used as a donor and acceptors respectively. The transglycosylation reaction by amylosucrase produced one or two major polyphenol glycosides depending on the type of polyphenols used. The synthesized polyphenol glycosides were detected by thin-layer chromatography. The structures of the newly synthesized polyphenol glycosides were predicted based on the transglycosylation mechanism of the enzyme. According to the acceptability of the polyphenols, the structural characteristics of polyphenol as an efficient acceptor were evaluated. The results indicate that amylosucrase is an efficient catalyst for the enzymatic synthesis of polyphenol glycosides, which have high potentials in food, cosmetics, and pharmaceutical industries.
\end{abstract}

Key words : Acceptor reaction, amylosucrase, polyphenol glycosides, transglycosylation

\section{서 론}

식물체에서 생산되는 폴리페놀 물질들은 식물체가 합성하 는 이차 대사산물이다. 폴리페놀은 식물체에서 식물 조직을 보호하고 지지하는 역할을 하며 화분 매개자인 곤충, 동물을 유인할 뿐만 아니라 다른 식물의 생장과 발달을 저해하기도 한다[7]. 더구나 폴리페놀은 식물과 주위 환경과의 상호 작용 에 있어서 신호전달 물질이며 식물이 죽은 뒤에도 몇 주 또는 몇 달간 분해되지 않고 유지되면서 토양에 존재하는 분해자와 분해 과정에 영향을 끼쳐 생태계에서도 중요한 역할을 가진다 [7]. 최근 들어 이러한 폴리페놀의 건강식품과 약품으로서 연 구가치가 증대되고 있으며, 이미 체내에 유익한 항염증, 항산 화와 항암 등의 잠재성이 확인되고 있다[1,3,4]. 그러나 폴리페 놀의 체내에 적용은 낮은 수용성으로 인해 흡수되는 양 보다 오히려 배설되는 양이 많고 세포독성을 가질 수 있다는 문제 점이 한계로 지적된다. 이런 문제점은 폴리페놀의 당화과정 (glycosylation)을 통하여 합성된 배당체를 이용하여 극복할 수 있다. 배당체의 합성은 화학적 방법으로 가능하지만, 이런 방법은 고온, 고압을 포함하는 조건이 필수적이고 합성된 아 노머(anomer) 물질의 분리 및 환경문제 등을 야기하여[18] 최 근에는 생물체가 지니는 당 전이 능력을 갖는 효소를 이용한 당 전이 반응(transglycosylation)을 통하여 빠르고 쉽게 생산 하고 있다[8,13]. 더욱이 효소적 방법은 위치특이적, 입체특이 적인 배당체 생산을 만들고 동시에 합성 반응이 일원화된다는 장점을 갖는다.

*Corresponding author Tel : +82-51-510-2196, Fax : +82-51-514-1778

E-mail : jhcha@pusan.ac.kr
당 전이 효소로는 기존에 당 분해 활성이 있는 glycosidase 를 이용하는 방법과 glycosyltransferase를 이용하는 방법이 있는데, glycosidase를 이용한 당 전이 반응은 공여체로 넓은 기질 특이성과 다양한 결합 구조를 갖는 전이산물을 합성할 수 있는 장점이 있는 반면 합성된 배당체가 효소에 의하여 다시 가수분해될 수 있어 전이산물의 수율이 낮다는 문제점이 있다[6,14,19]. Glycosyltransferase의 경우 전이 산물의 수율이 높은 반면 대부분 알려진 전이효소는 공여체로 산업화하기에 는 비싼 기질인 뉴클레오티드가 결합된 복합기질을 이용한다 는 점이 단점이다[6].

당 전이 효소 중에서도 뉴클레오티드가 결합된 복합기질이 아닌 sucrose를 기질로 이용하는 효소인 amylosucrase (EC 2.4.1.4)는 글루코사이드 가수분해효소의 13번째 family에 속 하는 알파 아밀라아제 타입의 효소로서 알파 1,4 글루코사이 드 결합을 통하여 다당류인 아밀로오스를 생산한다 [5,15, 16,20]. 이 효소는 수용체로서 글루칸 뿐만 아니라 카테킨[2], 살리신[10], 그리고 알부틴[17]을 수용체로 활용하여 포도당을 전이하는 능력이 있음이 확인되었다. 합성된 배당체의 수율도 기존의 당 전이 효소들에 비하여 월등히 우수하다는 것이 확 인되어 차후 다양한 산업적 용도에 적합한 효소로 판단되고 있다.

본 연구의 목적은 우수한 당 전이 능력을 보유한 효소로 알려진 amylosucrase 가 다양한 형태의 폴리페놀 화합물들을 수용체로 하여 새로운 형태의 배당체를 합성할 수 있는지를 검사하고자 하였다. 더 나아가 본 연구를 통하여 이 효소가 이용할 수 있는 수용체의 화학구조적 특징을 예측하였다. 


\section{재료 및 방법}

\section{실험재료}

본 실험에 사용된 amylosucrase는 대장균을 이용하여 재조 합 단백질의 형태로 생산하였으며[10], 사용된 폴리페놀 중 aloin, baicalein, cinnamic acid, ferulic acid, 4-hydroxycinnamic acid, hesperidin, linalool, morin, rutin, silymarin 그리 고 theophylline은 부산대학교 노화 조직 은행에서 분양받았 고, aesculin, arbutin, baicalin, caffeic acid, polydatin, resveratrol, vanillin, 그리고 zingerone은 Sigma에서 구매하였다. 또 한 salicin은 Alfa Aesar (Ward Hill, MA, USA)에서 구매하였 으며, aesculetin은 부산대학교 한의학 전문대학원 하기태 교 수 연구실에서 분양받아 사용하였다. 사용한 폴리페놀 화합물 들은 Table 1에 정리하였다.

\section{효소 활성 측정}

Amylosucrase의 활성은 $40 \mathrm{mg} / \mathrm{ml}$ 의 sucrose를 기질로 하 여 측정하였다. 반응액은 $50 \mathrm{mM}$ Tris-HCl buffer (pH 8.0)를 사용하였고, 효소액을 첨가하여 $45^{\circ} \mathrm{C}$ 에서 10 분간 반응하였다. 효소반응 후, 생성된 fructose의 양은 3,5-dintrosalicylic acid (DNS) 방법 을 이용하여 측정하였다[5]. 효소의 1 unit는 분당 $1 \mu \mathrm{mol}$ 의 fructose를 생성하는 효소의 양으로 정의하였다.

\section{당 전이 반응을 통한 배당체의 합성}

Amylosucrase의 배당체 합성 시 수용체인 폴리페놀의 구
조적 특징에 따른 전이능을 확인하기 위해, 공여체와 수용체 의 비율을 $1: 1(\mathrm{~mol} / \mathrm{mol})$ 로 하여 공여체로 $25 \mathrm{mM}$ sucrose 와 수용체로 aesculin, arbutin, vanillin, 그리고 zingerone을 각각 $25 \mathrm{mM}$ 로 첨가하여 전이 반응을 유도하였다[2]. 반응액 은 $50 \mathrm{mM}$ Tris-HCl buffer (pH 8.0)를 사용하였고 효소는 반응 액 $50 \mu \mathrm{l} \mathrm{당} 70 \mu \mathrm{g}$ 을 첨가하여 $30^{\circ} \mathrm{C}$ 에서 12 시간 동안 전이 반응 을 유도하였다. 반응시간에 따른 배당체 합성 정도를 측정하 기 위해 위와 같은 조건에서 $20 \mathrm{mM}$ sucrose와 $20 \mathrm{mM}$ aescu$\operatorname{lin}$ 을 공여체와 수용체로 각각 반응 하였고, $0,6,12,18$, 그리고 24 시간 전이 반응 후 전이 산물을 Thin layer chromatography (TLC)로 확인하였다.

\section{반응산물의 TLC 분석}

당 전이 산물의 확인과 분석은 TLC를 이용하였다. TLC는 Whatman K6F silica gel plates (Whatman, Maidstone, UK) 를 사용하였으며, 전개용매로 butanol/ethanol/water를 5:3:2 $(\mathrm{v} / \mathrm{v} / \mathrm{v})$ 로 혼합하여 사용하였다. TLC plate에 전이 반응액 1 $\mu \mathrm{l}$ 을 점적 후에 건조시키고, 전개용액에 넣어 일정 시간 동안 전개한 후, 공기 중에서 다시 건조 시켰다. 건조된 plate는 $254 \mathrm{~nm}$ 와 $366 \mathrm{~nm}$ 파장에서 폴리페놀이 갖는 ring 구조의 발 광을 통해 전이산물을 확인하였다. 또한 건조된 plate를 $0.3 \%$ (w/v) $N$-(1-naphthyl)-ethylenediamine과 5\% (v/v) $\mathrm{H}_{2} \mathrm{SO}_{4}$ 를 포함하는 methanol 용액에 빠르게 담근 후 완전히 건조한 다 음, $110^{\circ} \mathrm{C}$ 에서 10 분간 구워 전이 반응을 분석하였다.

Table 1. List of the natural polyphenols used in this study

\begin{tabular}{|c|c|c|}
\hline No. & Scientific name & Source \\
\hline 1 & Aesculetin (6,7-dihydroxy-2-chromenone) & horse chestnut \\
\hline 2 & Aesculin (esculetin 6- $\beta$-D-glucoside) & horse chestnut \\
\hline 3 & Aloin & aloe \\
\hline 4 & Arbutin (arbutoside hydroquinone $\beta$-D-glucopyranoside) & bearberry \\
\hline 5 & Baicalein (5,6,7-trihydroxy-2-phenyl-chromen-4-one) & Scutellaria baicalensis \\
\hline 6 & Baicalin (baicalein 7-Oglucuronide) & Scutellaria baicalensis \\
\hline 7 & Cinnamic acid ((E)-3-phenylprop-2-enoic acid) & shea butter \\
\hline 8 & Coumalic acid (4-hydroxycinnamic acid) & peanuts \\
\hline 9 & Caffeic acid (3-(3,4-dihydroxyphenyl)-2-propenoic acid) & cinnamon \\
\hline 10 & Ferulic acid (3-methoxy-4-hydroxycinnamic acid) & rice, coffee \\
\hline 11 & Hesperidin & citrus fruits \\
\hline 12 & Linalool (3,7-dimethylocta-1,6-dien-3-ol) & lime \\
\hline 13 & Morin (2-(2,4-dihydroxyphenyl)-3,5,7-trihydroxy-4H-1-benzopyran-4-one) & grape \\
\hline 14 & Rutin (rutoside) & buckwheat \\
\hline 15 & Resveratrol (trans-3,5,4'-trihydroxystilbene) & grape \\
\hline 16 & Piceid (3,4'-5-trihydroxystilbene-3- $\beta$-D-glucopyranoside) & Polygonum cuspidatum \\
\hline 17 & Salicin (2-(hydroxymethyl)phenyl- $\beta$-D-glucopyranoside) & willow bark \\
\hline 18 & Silymarin & thistle \\
\hline 19 & Theophylline(1,3-dimethyl-7H-purine-2,6-dione) & cocoa beans \\
\hline 20 & Vanillin (4-hydroxy-3-methoxybenzaldehyde) & vanilla bean \\
\hline 21 & Zingerone (4-(4-hydroxy-3-methoxyphenyl)-2-butanone) & ginger \\
\hline
\end{tabular}




\section{결과 및 고찰}

이전의 연구 결과로부터 당 전이 능력이 우수하다고 판단된 amylosucrase를 이용하여 21 종의 천연물 유래 폴리페놀을 수용체로 하여 다양한 폴리페놀에 대한 배당체 합성 능력을 검사하였다. Aesculin을 수용체로 시간별로 전이시켜 합성된 배당체를 TLC를 통해 확인하였다(Fig. 1A). 이 효소는 카테킨 을 이용한 배당체 합성 연구에서 공여체와 수용체의 비율이 $1: 1$ 인 조건에서 $30^{\circ} \mathrm{C}, 12$ 시간이 최적 당 전이 조건이라고 알려 져 있었지만 6시간의 전이 유도 후 얻어진 당 전이 산물은 12 시간에서 생성된 전이 산물의 양과 크게 차이가 없는 것을 확인하였다. Aesculin에 대한 전이 반응은 aesculin의 phenol ring이 $366 \mathrm{~nm}$ 에서 형광을 나타내는 것을 통해 쉽게 aesculin 과 aesculin의 전이 산물을 확인할 수 있었다(Fig. 1B). Amylosucrase에 관해 알려진 기본적인 특성은 설탕을 기질로 이용하여 arbutin, salicin 등을 수용체로 폴리페놀 중 당이 결 합된 위치(sugar moiety)에 포도당 한 개 또는 두 개를 a-1,4glucosidic linkage로 전이시켜 배당체를 합성하는 것으로 알 려져 있다[2,10,17].

본 연구에서는 arbutin과 salicin 등의 구조와 기본적으로 유사한 aesculin 및 polydatin과 같이 당이 결합된 폴리페놀과 당이 결합되어 있지 않은 폴리페놀인 caffeic acid, vanillin, zingerone 등을 이용하여 배당체 합성의 기전을 연구하였다. Aesculin과 arbutin 같이 포도당이 결합된 폴리페놀을 수용체 로 사용하였을 경우 하나 이상의 전이 산물이 확인되었으며, vanillin과 zingerone 같이 당이 존재하지 않는 폴리페놀을 수 용체로 하였을 경우에도 하나 이상의 전이 산물이 확인되었다 (Fig. 2). 이것은 amylosucrase가 일반적으로 당을 포함하는 폴리페놀의 경우에는 당 부위(sugar moiety)의 수산기
A.

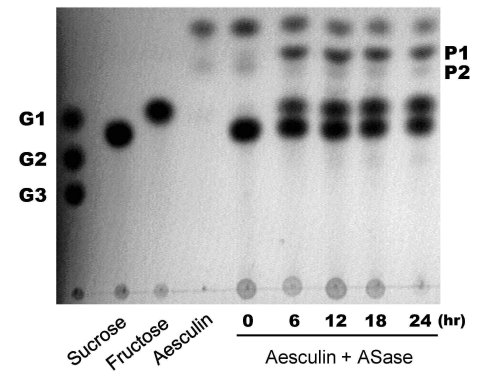

B.

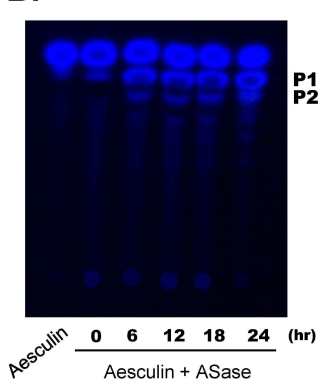

Fig. 1. TLC analysis of aesculin transglycosylation products as a function of time. (A) The spots were visualized by rapidly soaking in $0.3 \% N$-(1-naphtyl)-ethylenediamine and $5 \%(\mathrm{v} / \mathrm{v}) \mathrm{H}_{2} \mathrm{SO}_{4}$ in methanol. (B) The spots were visualized by UV detector at $366 \mathrm{~nm}$. The molar ratio of sucrose (donor) and aesculin (acceptor) in the reaction was $1: 1$. The enzyme reaction was performed in $50 \mathrm{mM}$ Tris- $\mathrm{HCl}$ buffer $(\mathrm{pH} 8)$ at $30^{\circ} \mathrm{C}$. The transfer products were labeled by $\mathrm{P} 1$ and $\mathrm{P} 2$, respectively.

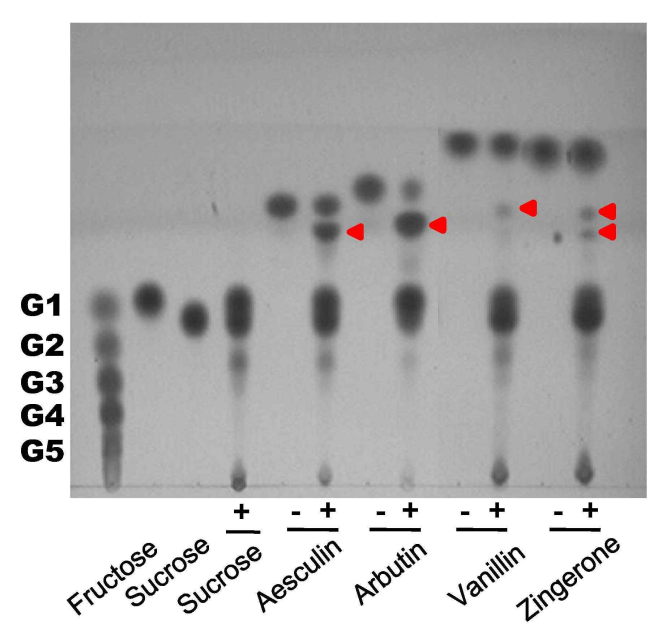

Fig. 2. TLC analysis of the transglycosylation products of various polyphenol compounds synthesized by recombinant amylosucrase. The reaction was carried out at $30^{\circ} \mathrm{C}$ for $6 \mathrm{hrs}$.

(hydroxyl group)에 우선적으로 당을 전이시키는 능력이 있다 는 것을 알 수 있으며, 또한 당이 존재하지 않는 폴리페놀의 경우에도 이 효소가 배당체를 합성할 수 있다는 점을 확인한 연구 결과이다. 우리의 연구 결과는 비당체인 폴리페놀로 알 려진 catechin을 수용체로 이전에 배당체를 합성하였다는 연 구 결과를 확인하였다[2]. 이렇게 합성된 폴리페놀 배당체는 자연계에서 존재하지 않는 새로운 형태의 배당체를 만들 수 있고, 이러한 새로운 배당체들이 기존의 폴리페놀 화합물들이 갖는 생리활성의 특성을 보다 개선할 수 있다는 점에서 큰 의의를 갖는다고 생각된다.

자연계에서 존재하는 당이 결합된 폴리페놀의 구조는 당과 비당체의 결합 형태가 $\beta$ 형태의 결합 구조를 취하는 반면[7], 이 효소를 이용하여 합성된 배당체는 폴리페놀 비당체 부분에 당이 a 형태의 결합 구조를 갖는다. a 형태로 합성된 폴리페놀 배당체는 자연계에 존재하지 않는 새로운 물질이며, 당 전이 를 통해 폴리페놀의 낮은 수용성을 증가시킬 수 있다는 점과 본래의 폴리페놀이 가지는 항산화, 항암, 항염증 및 미백과 같은 생리 활성을 향상시킬 수 있을 것이라 판단 된다[9,11,12]. Amylosucrase는 위의 다섯 종류의 폴리페놀을 제외하고 당이 존재 하지 않는 다른 폴리페놀에는 배당체를 합성하지 못하였 다(data not shown). 그 중, aloin, baicalin, hesperidin, rutin, 그리고 silymarin과 같은 분자량이 큰 물질은 효소의 기질 결 합부위에 수용체가 steric hindrance에 의하여 받아들이기 어 렵기 때문에 배당체 합성이 어려운 것으로 생각되며, morin의 경우 저해제로 관여하여 효소의 활성을 저해하여 배당체 합 성이 불가능한 것으로 판단된다. 또한 phenol ring에 수산기 가 존재하지 않는 cinnamic acid와 theophylline과 같은 폴리 페놀에는 당을 전이시킬 수 없었다. 그러나 수산기가 존재하 고 분자량도 크지 않은 4-hydroxy-cinnamic acid, ferulic 
A.

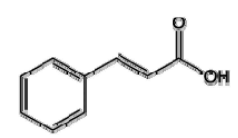

Cinnamic acid (FW 148.16)<smiles>O=C(O)/C=C/c1ccc(O)cc1</smiles>

4-hydroxycinnamic acid (FW 164.16)

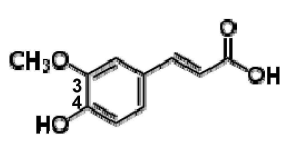

Ferulic acid (FW 194.18)
B.
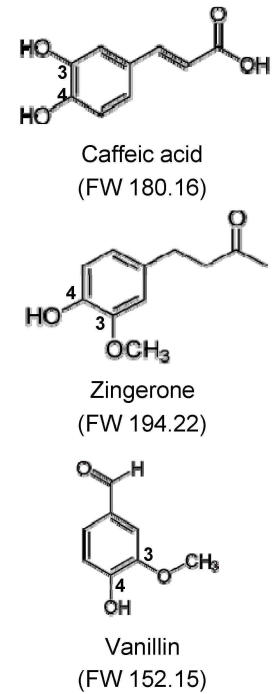

Fig. 3. The chemical structures of polyphenols used for transglycosylation reaction by amylosucrase. Group of polyphenolic compounds which are not working on acceptors (A) and the group of polyphenolic compounds working on acceptors (B).

acid, 그리고 linalool과 같은 폴리페놀 경우에도 전이반응이 일어나지 않았다. 전이가 가능한 수용체와 가능하지 않은 수 용체의 구조를 정리하여 본 결과 다양한 폴리페놀 화합물에 대한 전이능 분석 결과를 바탕으로 amylosucrase가 배당체 합성을 위해 수용체로 이용할 수 있는 폴리페놀들의 공통적인 구조적 특징을 파악할 수 있었다(Fig. 3). Cinnamic acid와 4-hydroxycinnamic acid를 수용체로 사용한 전이 반응의 경 우, 폴리페놀 전이산물은 합성되지 않았다(Fig. $3 \mathrm{~A}$ ). 하지만 두 폴리페놀과 구조가 유사하나 phenol ring의 3번 탄소 위치 에 수산기를 하나 더 가지는 caffeic acid의 경우 당 전이 산물 을 확인할 수 있었으며, 합성된 배당체는 phenol ring 의 3 번 탄소 위치에 당의 전이가 이루어졌을 것이라 예측할 수 있었 다. Zingerone 또한 위의 세 폴리페놀과 구조가 유사하나 phenol ring의 3번 탄소 위치에 methoxy기가 존재하는 차이로 인해 4 번 탄소 위치에 당을 전이시킬 수 있었던 것으로 생각된 다. Vanillin의 경우 phenol ring과 작용기의 구조적 형태가 zingerone과 유사하여 vanillin의 phenol ring의 4 번 탄소에 당이 전이되었을 것으로 생각된다(Fig. 3B). Ferulic acid는 zingerone의 구조와 거의 유사하지만 phenol ring의 탄소에 methoxy기가 Z 형태를 이루는 zingerone과 달리 $\mathrm{E}$ 형태의 입체배치를 형성하는 차이로 인해 당이 전이 되지 않는 것으 로 판단된다(Fig. 3A).

위의 결과를 토대로 amylosucrase를 이용한 신규 배당체 합성시 전이 가능한 폴리페놀의 수용체 구조를 정리하면 당이 존재하는 폴리페놀에는 당부위에 우선 적으로 당을 전이시키
고 phenol ring에 수산기가 하나 이상 존재하며 폴리페놀의 입체배치가 Z 이성질체 형태를 이루는 폴리페놀 구조에도 효 과적으로 배당체 합성이 가능할 것으로 예상된다. 현재 당을 포함하지 않는 다양한 폴리페놀에 당쇄를 부여하는 효소는 복합기질을 사용하는 glycosyltransferase와 특정 폴리페놀에 특이적인 폴리페놀 당 전이 효소외에는 알려진 것이 없다. 그 러므로 이 효소는 다양한 폴리페놀 화합물에 대한 배당체 합 성에 매우 효율적인 촉매로 판단된다. 앞으로 배당체 합성 수 율을 보다 더 증대시킬 수 있는 방법을 개발한다면 산업화에 활용 가능성이 높은 유용한 효소로 생각된다.

\section{감사의 글}

본 연구는 2010년도 국토해양부 해양생명공학사업 해양극 한생물분자유전체연구단 3 단계 사업의 지원에 의한 연구결 과의 일부이며, 폴리페놀 화합물을 분양해준 부산대학교 노 화 조직 은행과 한의학 전문대학원 하기태 교수님께 감사드 립니다.

\section{References}

1. Cao, G., E. Sofic, and R. L. Prior. 1997. Antioxidant and prooxidant behavior of flavonoids: structure-activity relationships. Free Radical Biol. Med. 22, 749-760.

2. Cho, H. K., H. H. Kim, D. H. Seo, J. H. Jung, J. H. Park, N. I. Baek, M. J. Kim, S. H. Yoo, J. Cha, Y. R. Kim, and C. S. Park. 2011. Biosynthesis of (+)-catechin glycosides using recombinant amylosucrase from Deinococcus geothermalis DSM 11300. Enzyme Microb. Technol. 49, 246-253.

3. González-Gallego, J., S. Sánchez-Campos, and M. J. Tuñón. 2007. Anti-inflammatory properties of dietary flavonoids. Nutr. Hosp. 22, 287-293.

4. Guo W, E. Kong, and M. Meydani. 2009. Dietary polyphenols, inflammation, and cancer. Nutr. Cancer 61, 807-810.

5. Ha, S. J., D. H. Seo, J. H. Jung, J. Cha, T. J. Kim, U. W. Kim, and C. S. Park. 2009. Molecular cloning and functional expression of a new amylosucrase from Alteromonas macleodii. Biosci. Biotechnol. Biochem 73, 1505-1512.

6. Hancock, S. M, M. D Vaughan, and S. G Withers. 2006. Engineering of glycosidases and glycosyltransferases. Curr. Opin. Chem Biol. 10, 509-519.

7. Jaganath, I. B. and A. Crozier. 2010. Dietary flavonoids and phenolic compounds, pp. 2-39, In Fraga, C. G. (eds.), Plant phenolics and human health Wiley, New Jersey.

8. Jiang, J. R., S. Yuan, J. F. Ding, S. C. Zhu, H. D. Xu, T. Chen, X. D. Cong, W. P. Xu, H. Ye, and Y. J. Dai. 2008. Conversion of puerarin into its 7-Oglycoside derivatives by Microbacterium oxydans (CGMCC 1788) to improve its water solubility and pharmacokinetic properties. Appl. Microbiol. Biotechnol. 81, 647-657.

9. Jun, S. Y., K. M. Park, K. W. Choi, M. K. Jang, H. Y. Kang, 
S. H. Lee, K. H. Park, and J. Cha. 2008. Inhibitory effects of arbutin- $\beta$-glycosides synthesized from enzymatic transglycosylation for melanogenesis. Biotechnol. Lett. 30, 743-748.

10. Jung, J. H., D. H. Seo, S. J. Ha, M. C. Song, J. Cha, S. H. Yoo, T. J. Kim, N. I. Baek, M. Y. Baik, and C. S. Park. 2009. Enzymatic synthesis of salicin glycosides through transglycosylation catalyzed by amylosucrases from Deinococcus geothermalis and Neisseria polysaccharea. Carbohydr. Res. 344, $1612-1619$.

11. Kim, H. K., B. S. Cheon, Y. H. Kim, S. Y. Kim, and H. P. Kim. 1999. Effects of naturally occurring flavonoids on nitric oxide production in the macrophange cell line RAW 264.7 and their structure-activity relationships. Biochem Pharmacol. 58, 759-765.

12. Kim, H. P., K. H. Son, H. W. Chang, and S. S. Kang. 2004. Anti-inflammatory plant flavonoids and cellular action mechanisms. J. Pharmacol. Sci. 96, 229-245.

13. Kren, V. and J. Thiem. 1997. Glycosylation employing bio-systems: from enzymes to whole cells. Chem Soc. Rev. 26, 463-473.

14. Lai-Xi, W. and H. Wei. 2009. Enzymatic transglycosylation for glycoconjugate synthesis. Curr. Opin. Chem Biol. 13, 592-600.

15. Potocki-Veronese, G., J. L. Putaux, D. Dupeyre, C. Albenne, M. Remaud-Siméon, P. Monsan, and A. Buleon. 2005.
Amylose synthesized in vitro by amylosucrase: morphology, structure, and properties. Biomacromolecules 6, 1000-1011.

16. Schneider, J., C. Fricke, H. Overwin, and B. Hofer. 2011. High level expression of a recombinant amylosucrase gene and selected properties of the enzyme. Appl. Microbiol. Biotechnol. 89, 1821-1829.

17. Seo, D. H., J. H. Jung, S. J. Ha, M. C. Song, J. Cha, S. H. Yoo, T. J. Kim, N. I. Baek, and C. S. Park. 2009. Highly selective biotransformation of arbutin to arbutin-a-glucoside using amylosucrase from Deinococcus geothermalis DSM 11300. J. Mol. Catal. B Enzym 60, 113-118.

18. Schmidt, R. R. 1986. New methods for the synthesis of glycosides and oligosaccharides. Are there alternative to the Koenigs-Knorr method? Angew. Chem Int. Ed Eng. 25, 212-235.

19. Shaikh, F. A. and S. G. Withers. 2008. Teaching old enzymes new tricks: engineering and evolution of glycosidases and glycosyltransferases for improved glycoside synthesis. Biochem Cell Biol. 86, 169-177.

20. Skov, L. K., O. Mirza, A. Henriksen, G. P. De Montalk, M. Remaud-Simeon, P. Sarçabal, R. M. Willemot, P. Monsan, and M. Gajhede. 2001. Amylosucrase, a glucan-synthesizing enzyme from the alpha-amylase family. J. Biol. Chem 276, 25273-25278.

\section{초록 : 재조합 아밀로수크라아제를 이용한 효율적인 폴리페놀 배당체의 합성 \\ 박현수 ${ }^{1}$ 최경화 ${ }^{1}$ - 박영돈 ${ }^{1}$ 박천석 ${ }^{2} \cdot$ 차재호 $^{1}$ * \\ (부산대학교 미생물학과, ${ }^{2}$ 경희대학교 생명과학대학 식품공학과)}

재조합 아밀로수크라아제의 폴리페놀 배당체를 합성하는 능력을 검사하였다. 이 효소의 효소작용 특성에 근거 하여 설탕을 기질로 사용하였으며 21 종류의 각기 다른 폴리페놀 화합물들이 수용체로 사용되었다. 당 전이 반응 은 사용한 폴리페놀에 따라 하나 또는 두 개의 주요 폴리페놀 배당체를 합성하였다. 합성된 폴리페놀 배당체들은 박막 크로마토그래피법을 이용하여 확인되었고, 새로이 합성된 배당체의 구조는 당 전이 작용 특성에 근거하여 예측되었다. 수용체로 가능한 폴리페놀의 구조적 특징들이 평가되었으며, 이러한 결과는 Deinococcus geothermalis 유래 아밀로수크라아제가 식품, 화장품, 및 제약산업에서 높은 잠재성을 갖는 폴리페놀 배당체의 효소적 합성에 매우 효율적인 촉매로 활용될 수 있다는 것을 보여준다. 